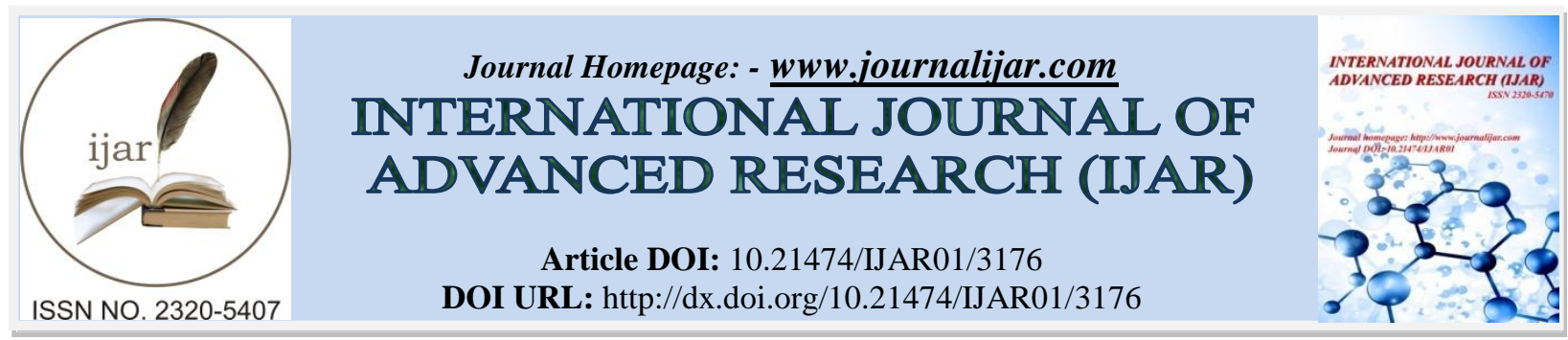

RESEARCH ARTICLE

\title{
STUDIES ON PERFORMANCE OF DROUGHT TOLERANT GENOTYPES UNDER DROUGHT AND NORMAL CONDITIONS THROUGH MORPHO, PHYSIO AND BIOCHEMICAL ATTRIBUTES OF BLACKGRAM (VIGNA MUNGO L.) AND GREEN GRAM (VIGNA RADIATA L.)
}

\author{
M. Pandiyan ${ }^{1}$, N. Senthil ${ }^{2}$, T. Balaji ${ }^{1}$, P.Veeramani ${ }^{1}$, B. K. Savitha ${ }^{1}$, V. Sendhilvel ${ }^{1}$ and A. Gopilkrishnan ${ }^{1}$. \\ 1. Agricultural Research Station, Virinjipuram, 632104 Vellore. \\ 2. Agricultural College and Research Institute, Madurai , Tamil Nadu.
}

\section{Manuscript Info}

\section{Manuscript History}

Received: 17 December 2016

Final Accepted: 08 January 2017

Published: February 2017

Key words:-

Quantitative characters, Leaf area,

Chlorophyll, Cell membrane stability,

Proline, Yields

\begin{abstract}
Six genotypes were studied of which each three genotypes from blackgram and greengram. Drought has been found to decline the almost all the morphological characters including leaf area in both the crops as compared to those of irrigated ones. The plant height is reduced, plants not having branches, even one or two plants having branches with shorter and unproductive, number of pods per plant, pod length and number of seeds per pod also much reduced. The hundred seed weight $(\mathrm{g})$, single plant yield and dry matter production $(\mathrm{kg} / \mathrm{ha})$ were reduced compared to irrigated condition. The susceptible genotypes of Co 8 in greengram and Co 6 in blackgram were much reduced in all the biometrical characters compared to water stress tolerant genotypes VRM(Gg)1 and VMGG012-005 in greengram and $\mathrm{VBN}(\mathrm{Bg}) 4$ and $\mathrm{VBN}(\mathrm{Bg}) 6$ in blackgram. Among the genotypes $\mathrm{CO} 8$ in greengram and CO 6 in blackgram had very low membrane stability. The reduction in photosynthesis under stress can also be attributed to a decrease in chlorophyll content in all the genotypes especially very high in Co 8 greengram and Co 6 in blackgram

The increased proline accumulation in drought tolerant genotypes of $\operatorname{VRM}(\mathrm{Gg}) 1$ and $\mathrm{VMGG} 012$-005 in greengram and $\mathrm{VBN}(\mathrm{Bg}) 4$ and $\operatorname{VBN}(\mathrm{Bg}) 6$ in blackgram are showed tolerance to drought. The correlation between the leaf proline content and soil moisture content was found to be negatively correlated at the same time correlation between chlorophyll Stability index (CSI) and soil moisture was found to be positively significant in both greengram and blackgram.
\end{abstract}

Copy Right, IJAR, 2017,. All rights reserved.

\section{Introduction:-}

Some of the existing ruling greengram and blackgram varieties have given minimum yield under water stress condition. To test verify the real fact of these varieties, the experiment was started with greengram and blackgram varieties. Water stress is abiotic factor affects plant's morphological, physiological and biochemical activities of the plant. Crop production is completed affected by periodical, regular and continuous droughts. Agriculture is the biggest consumer of water. Water is the main source involving for all activities of plant growth throughout the life of the crop plants. A complete Agriculture means which includes of seed to seed. Without soil seed will germinate 
but without water seed will not germinate. Water is essential medium for seed germination, seedling growth, vegetative period of the crops, flowering and translocate assimilate throughout the body of the plants from roots to top of the plants and leaf to bottom of the plants (Kijne., 2006) Food productivity is decreasing involved various factor such as drought, extreme temperature, cold, heavy metals, or high salinity, severely impair plant growth and productivity worldwide. But only Drought, being the most important environmental stress, severely impairs plant growth and development, limits plant production and the performance of crop plants, more than any other environmental factor (Shao et al., 2008). Accumulation of proline in plants is a well known tolerance mechanism to drought stress which acts as cellular osmotic adjustor and also protects and stabilizes essential cell components like protein, photosynthetic apparatus and detoxify Reactive Oxygen Species (ROS) etc. Pulse crops green gram (Vigna radiata L.) and black gram (Vigna mungo L.) are two most important protein sources that are grown in all over India as well as in Tamil Nadu. In addition, it also plays an important role in sustaining soil fertility by fixing atmospheric nitrogen. Therefore in the present experiment we tried to evaluate the various, morphological, physiological and biochemical changes taking place in selected pulse genotypes under drought stress and normal condition.

\section{Aims and objectives:-}

1. To study the greengram and blackgram genotypes under water stress and normal condition to test verify the reality of tolerance and confirmation through morphological, physiological and biochemical parameters

2. To observe the changes in these parameters during drought.

3. To study the overall effect of drought on yield components.

\section{Materials and Methods:-}

A total of six genotypes taken for this study, four genotypes already known for tolerant to drought and high temperature under normal cultivation at field level which are again test verify the real drought tolerance of the varieties under irrigated and drought conditions. The drought tolerant genotypes namely VRM(Gg)1 and VMGG012-005 in greengram and $\mathrm{VBN}(\mathrm{Bg}) 4$ and $\mathrm{VBN}(\mathrm{Bg}) 5$ in blackgram were imposed to drought and irrigated situation along with check varieties of Co 8 in greengram and Co 6 in blackgram. This trials was laid out during January- March 2016 at TNAU Agricultural Research Station Virinjipuram, Vellore. The seeds was sown in 4x3 $\mathrm{m}^{2}$ plot, four irrigations were given as per the schedule of $1^{\mathrm{st}}, 7^{\mathrm{th}}, 25^{\mathrm{th}}$ and $40^{\text {th }}$ DAS. During growth and reproductive periods no irrigation was given in drought imposed plot of both greengram and blackgram crops. The morphological characters were recorded in both condition of normal and drought imposed plots. The biometrical characters namely plant height $(\mathrm{cm})$, No. of branches / plant, Length of branches $(\mathrm{cm})$, No. of pods per plant, Pod length $(\mathrm{cm})$, No. of seeds per pod, Hundred seed weight (g), Seed yield / plant (g) and Dry matter production were recorded. The 10 plants from each genotypes were taken for work out the mean.

\section{Soil Analysis:-}

The collected soils were processed and analyzed for soil pH, EC using standard methods at the beginning of the experiments. Soil moisture was recorded immediately after second day of irrigation at middle of the plot in each in the irrigated plot and as same day soil moisture was also recorded in drought imposed. Soil moisture content was determined by gravimetric method at regular interval.

\section{Plant morpho-physiological analysis:- \\ Leaf membrane stability index:-}

Membrane stability index (MSI) was determined according to the method of Premchandra et al., 1990) as modified by (Sairam, 1997). Leaf materials $(0.1 \mathrm{~g})$ were thoroughly washed in running tap water at $40{ }^{\circ} \mathrm{C}$ for 30 min. After the expiry of the period their electrical conductivity was recorded by conductivity bridge (C1). Subsequently the same samples were placed in boiling water bath $\left(100{ }^{\circ} \mathrm{C}\right)$ for 10 min and their electrical conductivity recorded as above (C2). MSI was calculated with the following equation: $\mathrm{MSI}=[1-(\mathrm{C} 1 / \mathrm{C} 2)] \times 100$

\section{Leaf area index:-}

Leaves from 10 plants in each genotype were cut and leaf area was measured in $\mathrm{cm}^{2}$ by green leaf area meter (OSKModel GA-5).

\section{Plant biochemical analysis:-}

Chlorophyll-a, chlorophyll-b and total chlorophyll were determined. The carotenoid content were also estimated as per the procedure. Chlorophyll stability index was also calculated periodically using the following formula: (CSI \%) $=($ Total Chlorophyll under stress/Total Chlorophyll irrigated condition as control $) \times 100$. 


\section{Proline:-}

Determination of free Proline was estimated using the method of Bates et al. (1973). Samples were homogenized in $10 \mathrm{~mL} \mathrm{3 \% (w/v)} \mathrm{sulfosalicylic} \mathrm{acid,} \mathrm{and} \mathrm{proline} \mathrm{was} \mathrm{assayed} \mathrm{by} \mathrm{the} \mathrm{acid} \mathrm{ninhydrin} \mathrm{method.} \mathrm{The} \mathrm{absorbance} \mathrm{was}$ measured spectrophotometrically at $520 \mathrm{~nm}$. Proline was calculated based on $\mu \mathrm{M}$. g-1. FW. The Leaf proline content was analysed at $20^{\text {th }}$ DAS and $40^{\text {th }}$ DAS. The obtained data were analyzed using the statistical package PASW statistics.

\section{Results and Discussion:-}

In the present study which included six genotypes for the experiment and three genotypes from each crop of blackgram and greengram. During the crop period temperature and rainfall were recorded (Table 1.a). Soil moisture content was analyzed at four stages of the varietal plots and every time samples were taken for analysis at second day after irrigation (Table 1.) at both the conditions of Irrigated (Table 2) and drought (Table 3). There is no rainfall received during the entire period of the crop growth.

Table :- .a Weather data - January 15.1.2016 - March 31.3.2016 during the crop period

\begin{tabular}{|c|c|c|c|c|}
\hline Sl.No & Weekly Interval & Min Temp $\left({ }^{\mathbf{0}} \mathbf{C}\right)$ & Max Temp $\left({ }^{\mathbf{C}} \mathbf{)}\right.$ & Rainfall (mm) \\
\hline 1 & January -15.1 .2016 & 13.0 & 30.0 & 30.0 \\
\hline 2 & 22.1 .2016 & 13.0 & 30.57 \\
\hline 3 & 29.1 .2016 & 13.0 & 32.14 \\
\hline 4 & 5.2 .2016 & 13.0 & 32.71 \\
\hline 5 & 12.2 .2016 & 13.0 & 32.86 \\
\hline 6 & 19.2 .2016 & 13.43 & 35.0 \\
\hline 8 & 26.2 .2016 & 14.0 & 34.0 \\
\hline 9 & 4.3 .2016 & 14.0 & 34.29 \\
\hline 10 & 11.3 .2016 & 14.0 & 36.57 \\
\hline 11 & 18.3 .2016 & 14.0 & 38.57 \\
\hline 12 & 25.3 .2016 & 14.0 & 36.17 \\
\hline
\end{tabular}

Table 1:- Irrigation schedules for greengram and blackgram genotypes

\begin{tabular}{|l|l|l|l|l|l|}
\hline Genotypes & $\begin{array}{l}\text { First irrigation } \\
\text { DAS }\end{array}$ & $\begin{array}{l}\text { Second } \\
\text { irrigation } \\
\text { DAS }\end{array}$ & $\begin{array}{l}\text { Third } \\
\text { irrigation } \\
\text { DAS }\end{array}$ & $\begin{array}{l}\text { Fourth } \\
\text { irrigation } \\
\text { DAS }\end{array}$ & $\begin{array}{l}\text { Fifth } \\
\text { Irrigation } \\
\text { DAS }\end{array}$ \\
\hline Normal condition & 7.0 & 25.0 & 40 & 0.0 \\
\hline $\begin{array}{l}\text { All varieties greengram and } \\
\text { blackgram }\end{array}$ & 1.0 & 0.0 & 0.0 & 0.0 \\
\hline $\begin{array}{l}\text { Drought condition varieties greengram and } \\
\text { blackgram }\end{array}$ & 7.0 & & \\
\hline
\end{tabular}

Table 2:- Soil moisture content (\%) under irrigated condition

\begin{tabular}{|l|c|c|c|c|}
\hline Greengram & 2 DAS & 8 DAS & 26 DAS & 41 DAS \\
\hline VRM(Gg)1 & 92.50 & 95.20 & 88.32 & 87.35 \\
\hline VMGG 012-005 & 92.80 & 95.50 & 87.45 & 86.88 \\
\hline CO 8 & 92.30 & 95.60 & 87.80 & 87.76 \\
\hline Blackgram & 93.25 & 97.25 & 86.85 & 85.25 \\
\hline VBN(Bg)4 & 94.55 & 92.13 & 87.28 & 86.28 \\
\hline VBN(Bg)6 & 93.50 & 94.16 & 88.20 & 86.52 \\
\hline CO6
\end{tabular}


Table 3:- Soil moisture content (\%) under drought imposed condition

\begin{tabular}{|c|c|c|c|c|}
\hline \multicolumn{5}{|c|}{ Greengram } \\
\hline VRM(Gg)1 & 2 DAS & 8 DAS & 26 DAS & 41 DAS \\
\hline VMGG 012-005 & 91.20 & 93.10 & 40.12 & 22.20 \\
\hline CO 8 & 93.50 & 92.30 & 42.15 & 21.15 \\
\hline VBN(Bg)4 & 92.30 & 95.60 & 47.20 & 20.35 \\
\hline VBN(Bg)6 & 91.88 & 94.11 & 42.72 & 21.14 \\
\hline CO6 & 92.65 & 95.15 & 40.23 & 20.81 \\
\hline \multicolumn{7}{|c|}{ Blackgram } & 38.15 & 19.22 \\
\hline
\end{tabular}

\section{Effect of drought stress on plant growth parameters:-}

In the present study, plant growth parameters in terms of height and all biometric characters including leaf area were observed and are presented in Table 4, Table 5 and Table 6. Drought stress has been found to decline the almost all the morphological characters in both the crops as compared to those of irrigated ones. The plant height is reduced, most of the plants not having branches, even one or two plants having branches with shorter and unproductive , number of pods per plant, pod length and number of seeds per pod also much reduced. The hundred seed weight, single plant yield and dry matter production were reduced compared to irrigated condition. The susceptible genotypes of Co 8 in greengram and Co 6 in blackgram were much reduced in all the biometrical characters including leaf area compared to water stress tolerant genotypes which shows susceptible to water stress. This reduction in plant growth in terms of all quantitative characters are due to the loss of cell turgor which greatly suppresses cell expansion and cell growth thereby inhibiting the linear growth of shoot observed more in drought susceptible genotypes. Stress tolerant genotypes somewhat better than the susceptible genotypes towards yield. (Tahir and Mehid 2001) and Kamara et al., 2003.

Table 4:- Morphological characters of greengram and blackgram genotypes under normal condition

\begin{tabular}{|l|l|l|l|l|l|l|l|l|l|l|}
\hline Genotypes & $\begin{array}{l}\text { Plant } \\
\text { height } \\
(\mathrm{cm})\end{array}$ & $\begin{array}{l}\text { No. of } \\
\text { branches } \\
\text { / plant }\end{array}$ & $\begin{array}{l}\text { Length } \\
\text { of } \\
\text { branches } \\
(\mathrm{cm})\end{array}$ & $\begin{array}{l}\text { No. of } \\
\text { pods } \\
\text { per } \\
\text { plant }\end{array}$ & $\begin{array}{l}\text { Pod } \\
\text { length } \\
(\mathrm{cm})\end{array}$ & $\begin{array}{l}\text { No. of } \\
\text { seeds } \\
\text { per } \\
\text { pod }\end{array}$ & $\begin{array}{l}\text { Hundred } \\
\text { seed } \\
\text { weight } \\
(\mathrm{g})\end{array}$ & $\begin{array}{l}\text { Seed } \\
\text { yield } \\
\text { plant } \\
(\mathrm{g})\end{array}$ & $\begin{array}{l}\text { Dry matter } \\
\text { production } \\
(\mathrm{g})\end{array}$ \\
\hline Greengram \\
\hline VRM(Gg)1 & 35 & 3.2 & 27.5 & 28 & 9.8 & 10.2 & 3.2 & 8.0 & 28 \\
\hline $\begin{array}{l}\text { VMGG 012- } \\
\text { 005 }\end{array}$ & 21.0 & 1.5 & 13.0 & 18.0 & 8.0 & 8.1 & 3.2 & 7.5 & 15 \\
\hline CO 8 & 20.0 & 1.2 & 12.0 & 15.0 & 8.0 & 8.0 & 3.2 & 7.5 & 12 \\
\hline Blackgram & 30 & 3 & 28 & 45 & 6.0 & 7.3 & 4.2 & 9.0 & 25 \\
\hline VBN4 & 25 & 3 & 21 & 35 & 5.5 & 5.5 & 4.0 & 8.0 \\
\hline VBN6 & 27 & 3 & 18 & 25 & 5.5 & 5.0 & 4.1 & 7.8 & 21 \\
\hline CO6 &
\end{tabular}

Table 5:- Morphological characters of greengram and blackgram genotypes under drought condition

\begin{tabular}{|l|l|l|l|l|l|l|l|l|l|l|}
\hline Genotypes & $\begin{array}{l}\text { Plant } \\
\text { height } \\
(\mathrm{cm})\end{array}$ & $\begin{array}{l}\text { No. of } \\
\text { branches } \\
\text { /plant }\end{array}$ & $\begin{array}{l}\text { Length } \\
\text { of } \\
\text { branches } \\
(\mathrm{cm})\end{array}$ & $\begin{array}{l}\text { No. of } \\
\text { pods } \\
\text { per } \\
\text { plant }\end{array}$ & $\begin{array}{l}\text { Pod } \\
\text { length } \\
(\mathrm{cm})\end{array}$ & $\begin{array}{l}\text { No. of } \\
\text { seeds } \\
\text { per } \\
\text { pod }\end{array}$ & $\begin{array}{l}\text { Hundred } \\
\text { seed } \\
\text { weight } \\
(\mathrm{g})\end{array}$ & $\begin{array}{l}\text { Seed } \\
\text { yield } \\
\text { plant } \\
(\mathrm{g})\end{array}$ & $\begin{array}{l}\text { Dry matter } \\
\text { production } \\
(\mathrm{g})\end{array}$ \\
\hline Greengram \\
\hline VRM(Gg)1 & 22.0 & 1.0 & 15.0 & 12.0 & 7.5 & 6.0 & 2.8 & 3.0 & 15.0 \\
\hline $\begin{array}{l}\text { VMGG 012- } \\
\text { 005 }\end{array}$ & 15.0 & 0.0 & 0.0 & 7.0 & 5.6 & 5.0 & 2.2 & 2.2 & 7.0 \\
\hline CO 8 & 13.0 & 0.0 & 0.0 & 5.0 & 5.0 & 6.0 & 2.2 & 1.5 & 6.0 \\
\hline Blackgram & 20 & 1.0 & 13.0 & 15 & 5.0 & 5.0 & 4.0 & 5.0 & 13.0 \\
\hline VBN4 & 18 & 0.0 & 0.0 & 10 & 4.1 & 4.0 & 4.0 & 4.5 & 9.0 \\
\hline VBN6 & 15 & 0.0 & 12. & 3.0 & 4.5 & 4.0 & 3.8 & 3.5 & 8.0 \\
\hline CO6 &
\end{tabular}


Table 6:- Effect of drought stress on leaf area of greengram and blackgram genotypes

\begin{tabular}{|l|c|c|c|c|c|c|c|c|}
\hline Greengram & \multicolumn{2}{c|}{ Drrigated } & \multicolumn{5}{c|}{ Drought } \\
\hline & 2 DAS & 8 DAS & 26 DAS & 41 DAS & 2 DAS & 8 DAS & 26 DAS & 41 DAS \\
\hline VRM(Gg)1 & - & 0.70 & 8.5 & 9.5 & - & 0.71 & 6.8 & 5.9 \\
\hline VMGG 012-005 & - & 0.68 & 6.5 & 8.3 & - & 0.65 & 4.8 & 4.6 \\
\hline CO 8 & - & 0.65 & 6.8 & 8.2 & - & 0.64 & 4.1 & 3.3 \\
\hline Blackgram & - & 0.53 & 5.5 & 7.5 & - & 0.54 & 4.2 & 3.5 \\
\hline VBN(Bg)4 & - & 0.52 & 5.4 & 7.3 & - & 0.56 & 4.1 & 3.4 \\
\hline VBN(Bg)6 & - & 0.59 & 5.2 & 7.6 & - & 0.53 & 3.5 & 3.1 \\
\hline
\end{tabular}

Hence it can be inferred that the slow decline in this growth parameter might be due to lack of adequate moisture decreased day by day in plant root zone which can be evidenced from the positive correlation between soil moisture and height of the plant which is in confirmatory with the findings of earlier workers (Baroowa and Gogai 2012).

The reduction of leaf area was more prominent in all the varieties that faced longest period of water deficit (55 days). Even reduction in complete drought imposed situation and the tolerant genotypes has considerable yielding capacity been observed in the all four varieties when same situation imposed in the drought and susceptible genotypes completely lower in all the characters. But these drought tolerant varieties are having capable of the osmotic adjustment to cell alive to protect for longevity and maintain the cell turgor. In susceptible genotypes show reduction in cell division resulting in reduced cell number and stop cell elongation inhibiting leaf expansion. This study agreed with many authors, cell elongation of higher plants can be inhibited by interruption of water flow from the xylem to the surrounding elongating cells (Nonami, 1998). Drought caused impaired mitosis; cell elongation and expansion resulted in reduced growth and yield traits (Hussain et al., 2008). This modification in leaf anatomy is one of the basic causes which lead to reduction in average leaf size under water limiting situation (Bhaswatee Baroowa and Nirmali Gogoi 2012.). Plant height is a function of cell division, enlargement and differentiation (Hussain et al., 2008) and in redgram (Nam et al., 2001 and Kavar et al., 2007 and Sairam et al., 1997 and Saliendra et al 1995, Kaiser et al., 1981.

\section{Effect of drought stress on cell membrane stability:-}

The genotypes shows a considerable decrease in the membrane stability in the plants grown under drought stress condition as compared to the irrigated plants for both the crops (Table 7). Plants kept under more than 55 days of water deficit had the lowest membrane stability value compared to the plants grown irrigated condition. Among the genotype Co 8 in greengram and Co 6 in blackgram had very low membrane stability. The decrease in cell membrane stability was found to be more in greengram. The Membrane stability index was found to be positively correlated with soil moisture content for both black gram and green gram cultivars (Baroowa and Gogai 2012). The lower MSI of Co 8 greengram and Co 6 blackgram accompanied with the greatest seed yield loss of this genotype. While other had highest value of MSI with normal seed yield may indicate the underlying physiological mechanisms that contribute in water deficit tolerance. (Yeilaghi et al., 2012).

\section{Effect of drought stress on biochemical parameters:-}

In the present study, chlorophyll-a and chlorophyll-b content of both blackgram and greengram plants showed a decreasing trend with the increasing duration of drought which proved that these photosynthetic pigments are sensitive to water deficit condition Table 7. A continuous decrease in chlorophyll stability index was observed during the drought period more in CO 8 greengram and CO 6 blackgram. Chlorophyll Stability Index (CSI) is an indicator of the stress tolerance capacity of plants. A higher CSI helps plants to withstand stress through better availability of chlorophyll by maintaining more dry matter production and higher productivity. The drop down of CSI in greengram was faster than that of blackgram (Kiani et al., 2008) and (Baroowa and Gogai 2012) and Chaves (2002) and Cornic G.,Massacci, (1996).

The reduction in photosynthesis under water deficit stress can also be attributed to a decrease in chlorophyll content. Water deficit reduced the chlorophyll content in water deficit susceptible genotypes and increased in water deficit tolerant genotypes. These results are in agreement with those of other oilseed crop (Sesamum indicum) (Abraham et al., 2008). Differences in leaf chlorophyll content can be as an indicator of plant vigor and its capacity for photosynthesis, strongly dependent on chlorophyll content (Carter and Spiering, 2002). The significant variation for 
Chl a, Chl b and carotenoid content has also been reported by other researchers (Jonson et al., 1993). and Sharma and Hall 1991 and Nam et al.,2001 and kavar et al., 2007 and Long et al., 1994. and Kolyorea 1958. and Rahman and Ahmad 2004 and Zhang et al.,2008.

Table 7:- Membrane stability index (\%), Chlorophyll a, Chlorophyll b , Chlorophyll a/b and carotenoid of blackgram and greengram genotypes under normal and stress condition.

\begin{tabular}{|c|c|c|c|c|c|c|c|c|c|c|c|c|}
\hline \multirow[t]{2}{*}{ Genotypes } & \multicolumn{2}{|c|}{$\begin{array}{l}\text { Membrane } \\
\text { stability index }\end{array}$} & \multicolumn{2}{|c|}{ Chlorophyll a } & \multicolumn{2}{|c|}{ Chlorophyll b } & \multicolumn{2}{|c|}{$\mathrm{Chl} \mathrm{a}+\mathrm{b}$} & \multicolumn{2}{|c|}{ Chl a/b } & \multicolumn{2}{|c|}{ Carotenoid } \\
\hline & Irrig* & Drgt* & Irrig & Drgt & Irrig & Drgt & Irrig & Drgt & Irrig & Drgt & Irrig & Drgt \\
\hline \multicolumn{13}{|l|}{ Greengram } \\
\hline VRM $(\mathrm{Gg}) 1$ & 60.79 & 48.92 & 1.01 & 0.89 & 0.36 & 0.27 & 1.37 & 1.16 & 2.80 & 3.29 & 0.20 & 0.17 \\
\hline $\begin{array}{l}\text { VMGG012- } \\
005\end{array}$ & 59.30 & 55.24 & 0.88 & 0.64 & 0.18 & 0.16 & 1.06 & 0.8 & 4.88 & 4.0 & 0.22 & 0.22 \\
\hline Co 8 & 61.19 & 50.35 & 0.83 & 0.70 & 0.29 & 0.18 & 1.12 & 0.99 & 2.86 & 3.88 & 0.21 & 0.19 \\
\hline \multicolumn{13}{|l|}{ Blackgram } \\
\hline VBN(Bg)4 & 63.13 & 46.61 & 0.88 & 0.64 & 0.22 & 0.25 & 1.10 & 0.47 & 4.0 & 2.56 & 0.20 & 0.21 \\
\hline VBN(Bg)6 & 64.28 & 45.50 & 0.77 & 0.64 & 0.30 & 0.18 & 1.07 & 0.48 & 2.56 & 3.55 & 0.26 & 0.22 \\
\hline Co 6 & 65.28 & 42.91 & 0.87 & 0.76 & 0.29 & 0.23 & 1.16 & 0.52 & 3.0 & 3.30 & 0.24 & 0.13 \\
\hline
\end{tabular}

*Irrig: irrigated, Drgt: Drought, Chl: Chlorophyll

Proline accumulation helps in maintaining a better osmotic balance in plant cells suffering from water deficit. In the present study, more accumulation of proline was reported in leaf tissue with the increase in duration of drought stress (Table 8). Regular moisture supply through irrigation decreased the free proline content where as reverse the proline content is increased in leaf at water deficit condition. Varieties having different degree of drought resistance differ in their capacity to accumulate proline under stress. Resistant varieties like VRM(Gg)1 and VMGG012-005 in greengram and $\mathrm{VBN}(\mathrm{Bg}) 4$ and $\mathrm{VBN}(\mathrm{Bg}) 6$ in blackgram had accumulate higher level of proline under water stress. A similar trend was obtained by Ashraf and Ibram (2005), Ashraf and Foolad (2007) and Tawfik (2008) who found that osmoprotectants such as proline and glycine betaine (GB) were increased under drought stress. Ashraf and Foolad, 2007, Barrowa and Gogai 2012 and Bates et al ., 1973 and Sankar et al., 2008 and Mohamadkhani and Heidari 2008 and Sundaresan and Sudhakaran,1995.

Table 8:- Effect of proline content $\mu \mathrm{g} / \mathrm{g}$ fresh weight at different time of gap irrigation and drought imposed

\begin{tabular}{|c|c|c|c|c|}
\hline Genotypes & \multicolumn{4}{|c|}{ Free proline content $(\mu \mathrm{g} / \mathrm{g})$ fresh weight } \\
\hline & \multicolumn{2}{|c|}{ Irrigated } & \multicolumn{2}{|l|}{ Drought } \\
\hline \multicolumn{5}{|l|}{ Greengram } \\
\hline & $20 \mathrm{DAS}$ & 40 DAS & $20 \mathrm{DAS}$ & $40 \mathrm{DAS}$ \\
\hline VRM(Gg)1 & 60.5 & 60.6 & $162 .$. & 318.5 \\
\hline VMGG012-005 & 80.5 & 78.5 & 296.5 & 420.5 \\
\hline $\operatorname{Co8}$ & 52.1 & 52.4 & 254.4 & 262.5 \\
\hline \multicolumn{5}{|l|}{ Blackgram } \\
\hline $\mathrm{VBN}(\mathrm{Bg}) 4$ & 58.0 & 58.5 & 255.5 & 380.2 \\
\hline $\mathrm{VBN}(\mathrm{Bg}) 5$ & 49.0 & 48.6 & 425.5 & 568.5 \\
\hline Co6 & 35.2 & 35.0 & 268.0 & 266.5 \\
\hline
\end{tabular}

The correlation between the leaf proline content and soil moisture content was found to be negatively correlated (Table 9) at the same time correlation between chlorophyll Stability index (CSI) and soil moisture was found to be positively significant in both greengram and blackgram. ( Premachandra et al., 1992.) 
Table 9:- Correlation co-efficient of different parameters

\begin{tabular}{|c|c|c|c|c|c|c|c|c|c|c|c|c|}
\hline & \multicolumn{2}{|l|}{ TC } & \multicolumn{2}{|l|}{ CSI } & \multicolumn{2}{|l|}{ PRO } & \multicolumn{2}{|l|}{ MSI } & \multicolumn{2}{|l|}{ HT } & \multicolumn{2}{|l|}{ LA } \\
\hline $\begin{array}{l}8^{\text {th }} \\
\text { DAS }\end{array}$ & GG & BG & GG & BG & GG & BG & GG & BG & GG & BG & GG & BG \\
\hline MC & $.842 *$ & -.417 & $.827 *$ & $\mathbf{8 8 0}$ *** & $-.857 * *$ & $\begin{array}{l}-854 * * \\
\end{array}$ & .402 & .714 & .744 & $.780 *$ & .743 & .763 \\
\hline $\begin{array}{l}26^{\text {th }} \\
\text { DAS }\end{array}$ & & & & & & & & & & & & \\
\hline MC & $.806^{*}$ & $.805 *$ & $.858 * *$ & $.842 *$ & $-.858 * *$ & $\begin{array}{l}- \\
.881 * * *\end{array}$ & .670 & .728 & .507 & .527 & .435 & .5801 \\
\hline $\begin{array}{l}41^{\text {th }} \\
\text { DAS }\end{array}$ & & & & & & & & & & & & \\
\hline MC & .652 & $.808 *$ & $.828^{*}$ & $.853 * *$ & $-.885 * *$ & $\begin{array}{l}-872 * * * \\
\end{array}$ & .488 & .675 & .052 & .015 & .251 & -.030 \\
\hline
\end{tabular}

* Correlation significant at $0.05 \%$ probability level

** Correlation significant at $0.01 \%$ probability level

(MC- Moisture Content, TC - Total Chlorophyll, HT - Plant Height, LA - Leaf Area, CSI -

Chlorophyll Stability Index, MSI - Membrane Stability Index, PRO- Proline Content)

\section{Conclusion:-}

In the present experiment, it has been observed that both the pulse varieties namely VRM(Gg)1 and VMGG012-005 in greengram and $\mathrm{VBN}(\mathrm{Bg}) 4$ and $\mathrm{VBN}(\mathrm{Bg}) 6$ in blackgram were significantly somewhat better yielding capacity in water deficit condition by drought tolerance mechanism when compared to greengram variety Co 8 and blackgram variety Co 6 susceptible. These varieties withstand to all such characters of membrane stability, high proline and maintain cell turgor even highest degree of drought (55 days of water deficit). The varieties namely $\mathrm{VRM}(\mathrm{Gg}) 1 \mathrm{and}$ VMGG012-005 in greengram and $\mathrm{VBN}(\mathrm{Bg}) 4$ and $\mathrm{VBN}(\mathrm{Bg}) 6$ in blackgram has having physiological and biochemical capability for drought tolerance in water stress condition.

Acknowledgement; Thanks to institution for providing all inputs at needy time for completing the trials.

\section{References:-}

1. Abraham, S.S., Jaleel, C.A., Chang-Xing, Z., Somasundaram, R., Azooz, M.M.,Manivannan, P., Panneerselvam, R., 2008. Regulation of growth and metabolism bypaclobutrazol and ABA in sesamum indicum L. under drought condition. J. Mol. Sci.3, 57-66.

2. Ashraf M. and Foolad M.R.2007, Roles of glycinebetaine and proline in improving plant abiotic stress tolerance - Environ, Exp.Bot., 59 (2), 206-216.

3. Bates L. S., Waldren, R. P. and Teare I. D., Rapid determination of free proline for water-stress studies, Plant and Soil, 39, 205- 207, (1973).

4. Bhaswatee Baroowa and Nirmali Gogoi (2012). Effect of induced drought on different growth and biochemical attributes of black gram (vigna mungo l.) and green gram (Vigna radiata L.).Journal of Environ Res and development Vol. 6 No. 3A, Jan-March 2012.

5. Carter, A.G., Spiering, B.A., 2002. Optical properties of intact leaves for estimating chlorophyll concentration. J. Environ. Qual. 31, 1424-1432.

6. Chaves M.M., Pereira J.S., Maroco J., Rodriques M.L., Osorio M.L., Carvatho I., Ricardo C.P.P., Faria T. and Pinheiro C.,2002. How plants cope with water stress in the field photosynthesis and growth? AnnBot., 89, 907916.

7. Cornic G.,Massacci, A. (1996). Leaf photosynthesis under drought stress, in: Baker N.R., (Ed.), Photosynthesis and the Environment, Kluwer Academic Publishers, The Netherlands.

8. Hussain, M., M.A. Malik, M. Farooq, M.Y. Ashraf, M.A. Cheema, (2008). Improving drought tolerance by exogenous application of glycinebetaine and salicylic acid in sunflower, J. Agron. Crop Sci. 194,193-199.

9. Jonson, G.N., Scholes, J.D., Horton, P., Young, A.J., 1993. Relationships betweencarotenoids composition and growth habit in British plant species. Plant Cell Environ.16, 681-686.

10. Kaiser W.M., Prachuab G., Kaiser G., Wildmann S.G., and Heber U.,1981 Photosynthesis under osmotic stress. Inhibition of photosynthesis of intact chloroplasts, protoplasts and leaf slices at high osmotic potentials, Planta, 153,416-422. 
11. Kamara A.Y., A. Menkir B. Badu-Apraku and Ibikunle, 2003. The influence of droughtstress on growth, yield and yield components of selected maize genotypes, J. Agric. Sci., 141 (1), 43-50.

12. Kavar T., Maras M., Kidric M., Sustar-Vozlic J., Meglic V. (2007). Identification of genes involved in the response of leaves of Phaseolus vulgaris to drought stress, Mol. Breed. 21, 159-172.

13. Kiani S.P., Maury P., Sarrafi A. and Grieu P.,2008. QTL analysis of chlorophyll fluorescence parameters in sunflower (Helianthus annus L.) under well-watered and water-stressed conditions, Plant Sci., 175 (4), 565-573.

14. Kijne, J.W.,2006. Abiotic stress and water scarcity: Identifying and resolving conflicts from plant level to global level, Field Crops Res., 97 (1), 3-18.

15. Koleyoreas S. A.,1958. A new method for deter- mining drought resistance, Plant Physiol., 33 (1), 22.

16. Long S.P., Humphries S. and Falkowski P.G., 1994. Photoinhibition of photosynthesis in nature, Annu. Rev. Plant Physiol. Plant mol. Biol., 45: 633-662.

17. Mohammadkhani N. and Heidari R.,2008. Drought-induced accumulation of soluble sugars and proline in two maize varieties, World App. Sci.s J., 3 (3): 448-453.

18. Nam N.H., Chauhan Y.S., Johansen C. (2001) Effect of timing of drought stress on growth and grain yield of extra-short-duration pigeonpea lines, J. Agr. Sci. 136, 179-189.

19. Nonami H. (1998) Plant water relations and control of cell elongation at low water potentials, J. Plant Res. 111, 373-382.

20. Premachandra G.S., Saneoka H., Fujita, K., Ogata S., 1992. Leaf water relations, osmotic adjustments, cell membrane stability, epicuticular wax load and growth as affected byincreasing water deficits in sorghum, $J$. Exp. Bot., 43 (12), 1569-1576, (1992).

21. Rahman M.U., Gul S. and Ahmad I., 2004. Effects of water stress on growth and photosynthetic pigments of corn (Zea maize L.) cultivars, Int. J. Agric. Biol., 4,652-5.

22. Sairam R.K., Deshmukh P.S. and Sukla D.S., 1997. Tolerence to drought and temperature stress in relation to increased antioxidant enzyme activity in wheat, J. Argon. Crop Sci., 178,171-177.

23. Saliendra N.Z., Sperry J.S. and Comstock J.P., 1995. Influence of leaf status on stomatal response to humidity, hydraulic conductance and soil drought in Betula occidentallis, Planta, 196, 357-366.

24. Sankar P.V., Murali M., Gomathinayagam G.M., Lakshmanan A. and Panneerselvam R., 2008. Water deficit stress effects on reactive oxygen metabolism in Catharanthus roseus, Colloids Surf. B: - Biointerface, 62 (1),105- 111.

25. Shao H.B., Chu L.Y., Shao M.A., Jaleel Abdul C. and Hong-Mei M.,2008. Higher plant antioxidants and redox signaling under environmental stresses, Comp. Rend. Biol., 331,433-441.

26. Sharma P.K. and Hall D.O.,1991. Interaction of salt stress and photoinhibition on photosynthesis in barley and sorghum, J. Plant Physiol., 138 (5):614-619.

27. Sundaresan S. and Sudhakaran P.R.,1995 Water stress-induced alterations in proline metabolism of droughtsusceptible and -tolerant cassava (Manihot esculenta) cultivars, Physiol Plant, 94, 635-642.

28. Tahir M.H.N. and. Mehid S.S.,2001 Evaluation of open pollinated sunflower (Helianthus annuus L.) populations under water stress and normal conditions, Int. J. Agric. Biol., 3, 236-238.

29. Tawfik KM (2008).Effect of Water Stress in Addition to Potassiomag Application on Mungbean. Australian J. Basic Appl. Sci. 2(1):42-52.

30. Yeilaghi, H., Arzani, A., Ghaderian, M., Fotovat, R., Feizi, M., Pourdad, S.S., 2012. Effect of salinity on seed oil content and fatty acid composition of safflower (Carthamustinctorius L.) genotypes. Food Chem. 130, 618625 .

31. Zhang, M., Zhai, Z., Tian, X., Duan, L., Li, Z., 2008. Brassinolide alleviated the adverseeffect of water deficits on photosynthesis and the antioxidant of soybean (Glycine maxL.). Plant Growth Regul. 56, 257-264. 